\title{
Gymnotocinclus anosteos, a new uniquely-plated genus and species of loricariid catfish (Teleostei: Siluriformes) from the upper rio Tocantins basin, central Brazil
}

\author{
Tiago Pinto Carvalho, Pablo Lehmann A. and Roberto E. Reis
}

\begin{abstract}
Gymnotocinclus anosteos, a new genus and species, is described from a headwater stream of the upper rio Tocantins basin in central Brazil. The new taxon is distinguished from other loricariids by the extreme reduction of dermal plates, having an almost completely naked body. Three other diagnostic features are: the absence of the lateral connecting bone, absence of bifid hemal spines, and odontode tips in the last dermal plates on the caudal peduncle dorsally or anteriorly curved. These derived features are not shared with any other hypoptopomine genus and the new taxon is hypothesized to be a basal member of the subfamily. Character states proposed by previous phylogenies of the subfamily are examined in the new taxon and its relationships are discussed.
\end{abstract}

Gymnotocinclus anosteos, novo gênero e espécie, é descrito de um córrego de cabeceira da bacia do alto rio Tocantins no Brasil central. O novo táxon é distinto de outros loricarídeos pela extrema redução das placas dérmicas, apresentando o corpo quase completamente sem placas. Três outras características diagnósticas são: a ausência do osso lateral, ausência de espinhos hemais bífidos e a presença de odontódeos na última série de placas dérmicas do pedúnculo caudal dorsalmente ou anteriormente curvados. Estas características derivadas não são compartilhadas com nenhum outro gênero de Hypoptopomatinae e o novo taxon é hipotetizado como membro basal da subfamília. Os estados de caracteres propostos por filogenias anteriores da subfamília são examinados e suas relações são discutidas.

Key words: Neotropical, Loricariidae, Taxonomy, Endemism, Cascudinhos.

\section{Introduction}

The Hypoptopomatinae is a monophyletic group of the Loricariidae, including more than 80 species grouped in 18 genera (Schaefer, 2003; Reis \& Carvalho, 2007). They are small fishes, widely distributed throughout cis-Andean drainages of South America from Venezuela to northern Argentina (Schaefer, 2003). The first cladistic study of hypoptopomatines was published by Schaefer (1991). Subsequently, the discovery of new generic- and species-level taxa prompted a re-evaluation of the phylogeny and classification of Schaefer's (1991) scheme, which divided the subfamily in two monophyletic groups, the tribes Otothyrini and Hypoptopomatini (Schaefer, 1998). More recently Gauger \& Buckup (2005) reanalyzed Schaefer's (1998) data matrix, including new taxa and characters, and suggested that the Otothyrini is paraphyletic. Finally, Lehmann (2006) also found a non-monophyletic Otothyrini, and discovered several new species, corroborating the prediction of Reis \& Schaefer (1998) about the diversity of hypoptopomatine loricariids being much greater than had been previously recognized.
During a survey of hypoptopomatine specimens in the fish collection of the Museu de Ciências Naturais (MCN) in Porto Alegre, RS, Brazil, we found an unusual loricariid that is almost completely devoid of dermal plates on the body surface. It has, on the other hand, traits that clearly place it among the Hypoptopomatinae, including a laterally exposed pectoral girdle, a compound pterotic pierced by numerous enlarged fenestrae, and a partially closed arrector fossae of the ventral pectoral girdle (Schaefer, 1998). This species is from the upper reaches of the rio Tocantins drainage in central Brazil, and is herein described as a new taxon. Comments on its relationships within the subfamily are also presented.

\section{Material and Methods}

Measurements were made to the nearest $0.1 \mathrm{~mm}$ with digital calipers under a stereomicroscope on the left side of specimens following Boeseman (1968, fig. 5), with the exception of trunk length, which was measured as the distance from the origin of pectoral-fin spine to the anterior origin of the pelvic fin. Additional measurements are suborbital depth, the dis-

Laboratório de Sistemática de Vertebrados, Pontifícia Universidade Católica do Rio Grande do Sul, Av. Ipiranga 6681, Caixa Postal 1429, 90619-900 Porto Alegre, RS, Brazil. tiagobio2002@yahoo.com.br, reis@pucrs.br 
tance between the lower margin of the bony orbit and the ventrolateral limit of the head, and mandibular ramus, the transverse width of the dentary. Morphometric data are expressed as percents of standard length (SL), except subunits of the head which are expressed as percents of head length. Plate counts and nomenclature follow the schemes of serial homology proposed by Schaefer (1997). Vertebral counts include all vertebrae (including the five centra modified into the Weberian apparatus), with the compound caudal centrum (PU1+U1) counted as one element. Cleared and stained specimens (c\&s) were prepared according to the method of Taylor \& Van Dyke (1985). Osteological nomenclature follows Schaefer (1997). Abbreviations in Figures are: AA = compound anguloarticular; $\mathrm{AH}=$ anterohyal; $\mathrm{BB}=$ basibranchial; $\mathrm{BO}=$ basioccipital; $\mathrm{BPT}=$ basipterygium; $\mathrm{BR}=$ branchiostegal ray; $\mathrm{CB}=$ ceratobranchial; $\mathrm{CBF}=$ ceratobranchial flange; $\mathrm{CL}=$ cleithrum; $\mathrm{CO}=$ coracoid $; \mathrm{CP}=$ cheek plate $\mathrm{CPt}=$ compound pterotic; $\mathrm{D}=$ dentary $; \mathrm{EB}=$ epibranchial; $\mathrm{EX}=$ exoccipital $; \mathrm{F}=$ frontal; $\mathrm{HB}=$ hypobranchial; $\mathrm{HH}=$ hypohyal; $\mathrm{HM}=$ hyomandibula; IO1-IO5 = infraorbitals; LE = lateral ethmoid; $\mathrm{LEE}=$ lateral ethmoid exposed area; LPT = lateropterygium; $\mathrm{ME}=$ mesethmoid; $\mathrm{MEC}=$ mesethmoid condyle; $\mathrm{MPT}=$ metapterigoid; $\mathrm{MX}=$ maxilla; $\mathrm{N}=$ nasal; $\mathrm{NC}=$ nasal capsule; $\mathrm{OP}=$ opercle; $\mathrm{OS}=$ orbitosphenoid; $\mathrm{PAL}=$ palatine; $\mathrm{PB}=$ infra-pharyngobranchial; $\mathrm{PF}=$ prefrontal plate; $\mathrm{PH}=$ posterohyal; $\mathrm{PMX}=$ premaxilla; $\mathrm{PN}=$ pre-nasal plate; $\mathrm{PO}=$ prootic; $\mathrm{POP}=$ preopercle; $\mathrm{PR}=$ postrostral plate; $\mathrm{PS}=$ parasphenoid; $\mathrm{PSB}=$ palatine sesamoid bone; $\mathrm{PTS}=$ pterosphenoid; $\mathrm{Q}=$ quadrate; $\mathrm{R}=$ rostral plate; $\mathrm{RB} 6=$ sixth rib; $\mathrm{SOC}=$ parieto-supraoccipital; $\mathrm{SP}=$ sphenotic; $\mathrm{TVP}=$ transverse process of the Weberian complex; $\mathrm{UH}=$ urohyal; $13 \mathrm{~V}=$ thirteenth vertebra.

Specimens examined belong to the following institutions: ANSP, Academy of Natural Sciences, Philadelphia; LBP, Laboratório de Biologia de Peixes, UNESP, Botucatu; MCN, Museu de Ciências Naturais, Fundação Zoobotânica do Rio Grande do Sul, Porto Alegre; and MCP, Museu de Ciências e Tecnologia, Pontifícia Universidade Católica do Rio Grande do Sul, Porto Alegre.

\section{Results}

\section{Gymnotocinclus, new genus}

Type species: Gymnotocinclus anosteos, by original designation (Fig. 1).

Diagnosis. Gymnotocinclus is distinguished from all other hypoptopomatine genera by the following uniquely derived features: (1) extreme reduction of body dermal plates (Fig. 2), (2) absence of the lateral connecting bone, (3) absence of bifid hemal spines on the abdominal vertebrae posterior to the first anal-fin proximal radial (Fig. 3), and (4) odontode tips on last dermal plates on the caudal peduncle dorsally or anteriorly curved (Fig. 4). Gymnotocinclus is also distinguished by a number of non-exclusive traits: maxillary barbel adnate to the lower lip; lateral ethmoid almost completely encapsulating the nasal organ (Fig. 5); ventral margin of preopercle straight, not deflected medially; pectoral girdle exposed and supporting odontodes only in a restricted lateral area near base of pectoral fin (Fig. 6); and absence of a pectoral-fin slit.

Etymology. From the Greek Gymnos, naked, and Otocinclus, a genus of the Hypoptopomatinae, in allusion to the extreme reduction of the body encasing dermal plates.

\section{Gymnotocinclus anosteos, new species}

Figs. 1-2

Holotype. MCN 18624, $44.3 \mathrm{~mm}$ SL, male, Brazil, Goiás, Alto Paraíso de Goiás, ribeirão das Cobras, near to road GO-239, tributary to rio Tocantinzinho, rio Tocantins basin, $14^{\circ} 09^{\prime} 43^{\prime \prime} \mathrm{S}$ 47³7'57"W, 9 Nov 1996, W. R. Koch \& K. M. Grosser.

Paratypes. All from Brazil, Goiás, Alto Paraíso de Goiás. MCN 13543, 12, 25.8-39.3 mm SL and MCP 41726, 5, 22.1-41.6 mm SL $+3 \mathrm{c} \& \mathrm{~s}, 22.4-40.5 \mathrm{~mm} \mathrm{SL}$, collected with the holotype. MCN 13154, 7, 16.3-34.3 mm SL, MCN 13155, 6, 19.0-31.6 mm SL, and ANSP $187156,5,22.5-40.8 \mathrm{~mm}$ SL, same locality as holotype, 4 Aug 1996, W. R. Koch, P. C. C. Milani \& K. M. Grosser. MCN $13538,1,28.1 \mathrm{~mm} \mathrm{SL}$, creek on road GO-239, tributary to rio Tocantinzinho, rio Tocantins basin, $14^{\circ} 08^{\prime} 22^{\prime \prime S} 47^{\circ} 39^{\prime} 45^{\prime \prime} \mathrm{W}, 9$ Nov 1996, W. R. Koch \& K. M. Grosser.

Diagnosis. Same as for genus.

Description. Morphometrics and meristics given in Tables 1 and 2 respectively. Dorsal profile gently curved from snout tip to parieto-supraoccipital bone, almost straight from that point to dorsal-fin origin. Slightly concave to straight at dorsal-fin base. Straight from end of dorsal-fin base to caudal-fin origin. Ventral profile straight to slightly convex from snout tip to posterior border of lip, straight and posteroventrally sloped from that point to origin of pelvic fin, straight and posterodorsally inclined from pelvic fin to caudal-fin origin. Body flattened at predorsal region. Ventral surface of trunk flattened at base of paired fins. Caudal peduncle round in cross section. Greatest body depth at dorsal-fin origin. Least body depth at posterior end of caudal peduncle. Head and snout broad, snout anterior margin rounded in dorsal view. Body progressively narrowing posteriorly from cleithrum. Head flattened at parieto-supraoccipital, interorbital region straight. Upper margin of orbit not elevated. Eye small, dorsolaterally placed. Iris operculum small, less than half pupil diameter.

Pectoral fin I,6, posterior margin slightly rounded; when depressed reaching to middle of adpressed pelvic fin. Posterior margin of pectoral-fin spine smooth. Soft portion of pectoral spine large, about one-fourth of spine length. Pectoralfin axillary slit absent. Coracoid and cleithrum exposed laterally, supporting odontodes only in restricted lateral area near base of pectoral fin; covered by skin medially (Fig. 6). Pelvic fin i,5, reaching anal-fin origin when depressed. Pelvic girdle with slender lateropterygium, club shaped, expanded proximally and thinner distally. Basipterygium ossified anteriorly, 
lacking anterior fenestrae (Fig. 7). Dorsal fin II,7; spinelet present, reduced in size, quadrangular in shape. Nuchal plate present, triangular in shape. Dorsal-fin origin located posterior to vertical through pelvic-fin origin. Anal fin i,5, first analfin pterygiophore not exposed on ventral surface anterior to first anal-fin unbranched ray. Bifid hemal spines absent from abdominal vertebrae posterior to first anal-fin proximal radial. Caudal fin i,14,i. Compound hypurals 1 and 2 almost completely fused to the compound hypurals $3-5$, posterior margin of caudal-fin skeleton with slight median notch. Total verte- brae 28-29 (3 c\&s). Adipose fin absent, single series of three to six platelets at adipose fin position.

Head plates present, including postrostral plates, infraorbital series, cheek plates, and small scattered plates anterior to nostril. Body almost completely naked, without dermal plates (Fig. 2), except for small platelets scattered all over body dorsal surface, not forming regular series; small platelets at lateral line composing median series; about six large plates on anterior portion of mid-ventral series; and last plates of ventral and dorsal series from adipose fin region to poste-

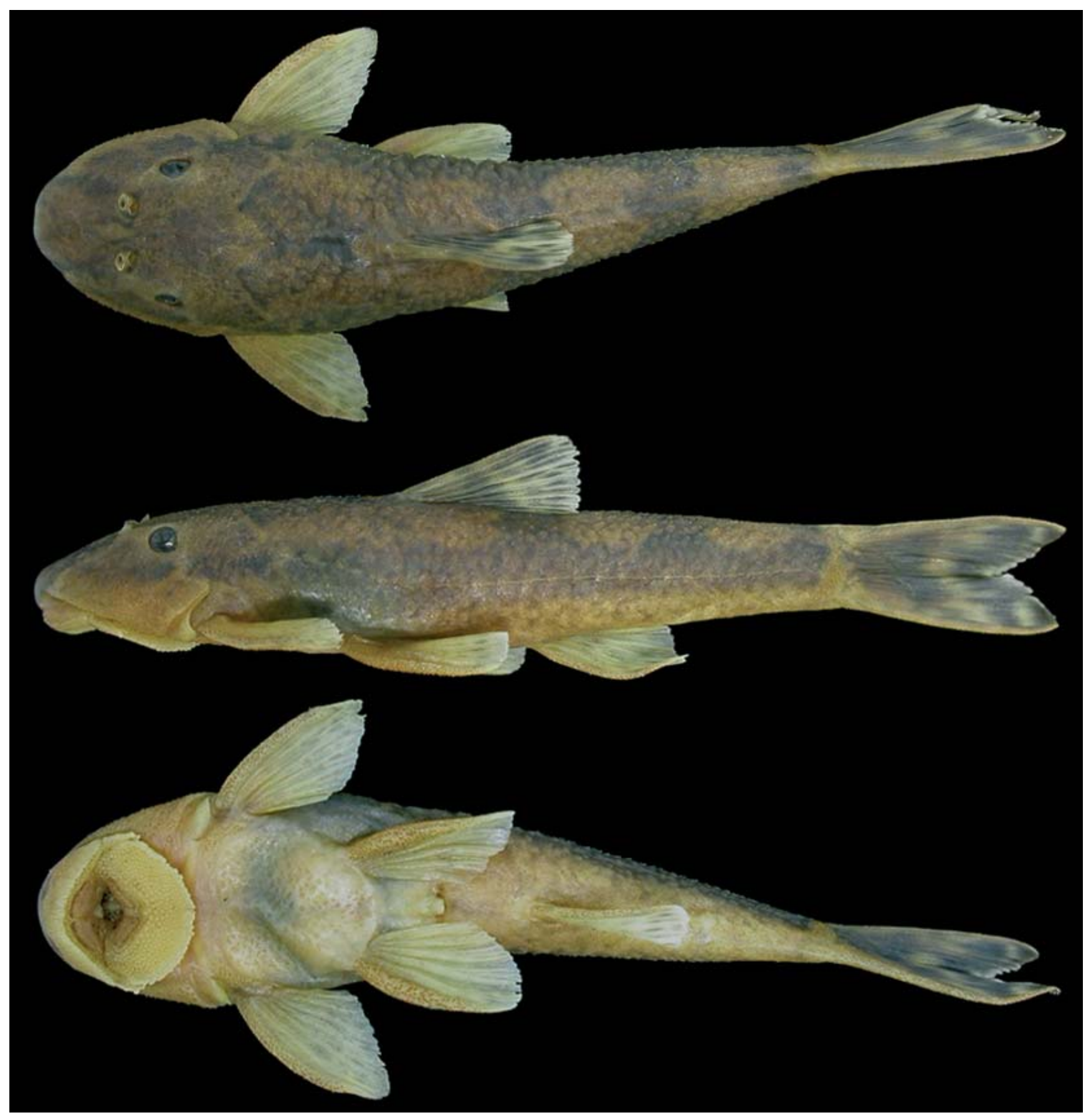

Fig. 1. Gymnotocinclus anosteos, holotype, MCN 18624, male, $44.3 \mathrm{~mm} \mathrm{SL}$, ribeirão das Cobras, near highway GO-327, tributary of rio Tocantinzinho, rio Tocantins Basin, Alto Paraíso de Goiás, Goiás, Brazil. 


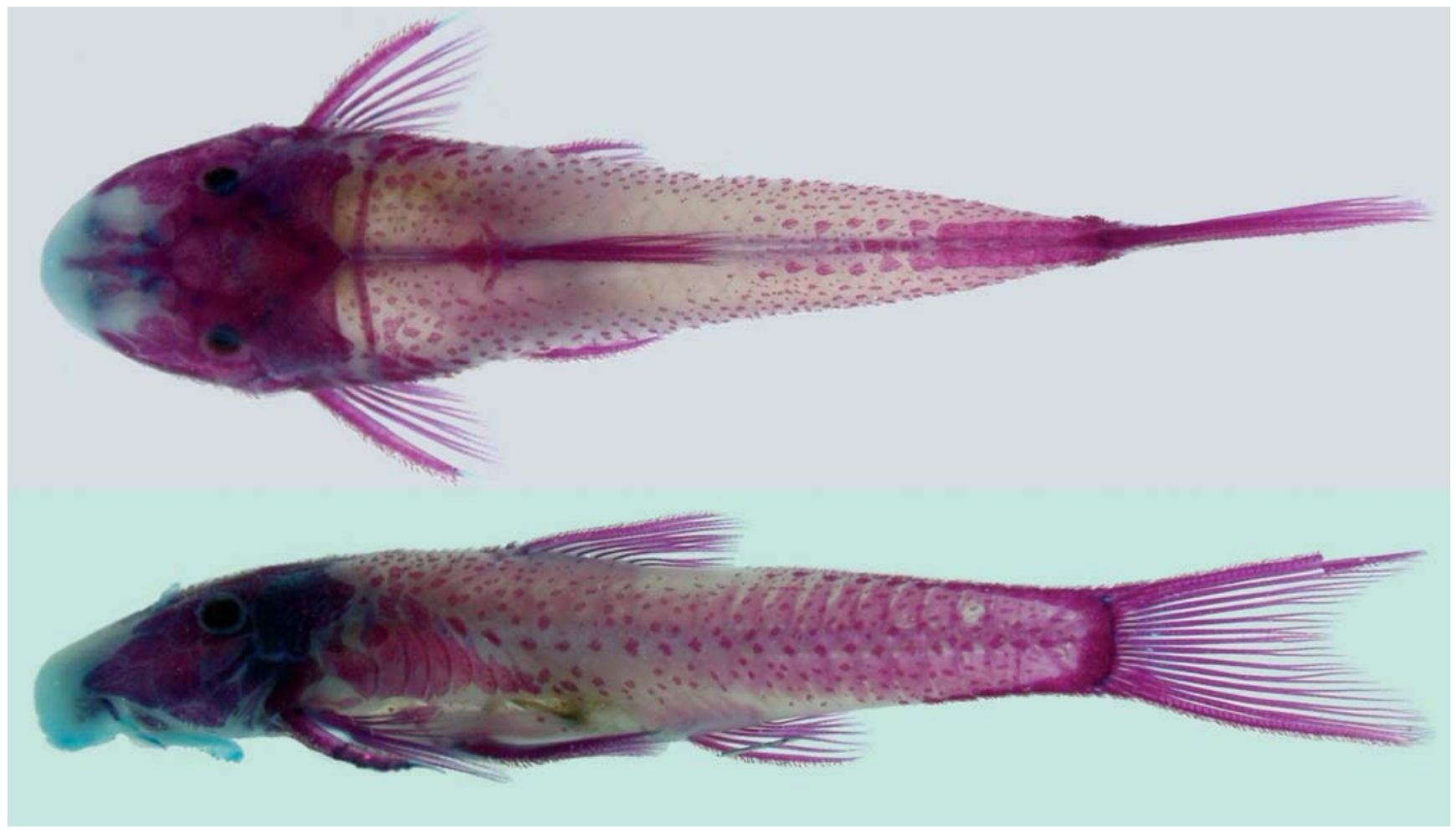

Fig. 2. Gymnotocinclus anosteos, cleared and stained paratype, MCP 41726, male, $40.5 \mathrm{~mm}$ SL, collected with the holotype.

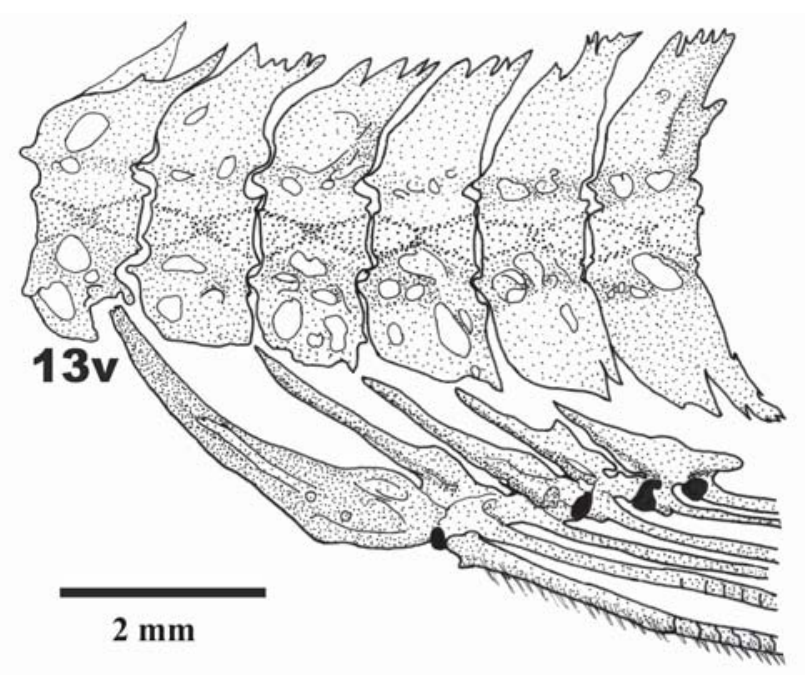

Fig. 3. Posterior abdominal vertebrae of Gymnotocinclus anosteos lacking bifid hemal spines. MCP 41726, paratype, male, $40.5 \mathrm{~mm}$.

rior end of caudal peduncle. Abdomen with scattered platelets irregularly arranged between posterior margin of coracoid and region anterior to anal-fin origin; abdominal platelets absent near pelvic-fin base. Fourth infraorbital not expanded ventrally, naked area below infraorbitals four and five and anterior to preopercle (Fig. 8). Infraorbital canal entering infraorbital series via sphenotic. Canal-bearing cheek plate not extending medially in ventral view. Lateral line complete, without midbody gap. Raised odontodes absent from parieto-supraoccipital in adults, smaller juveniles with

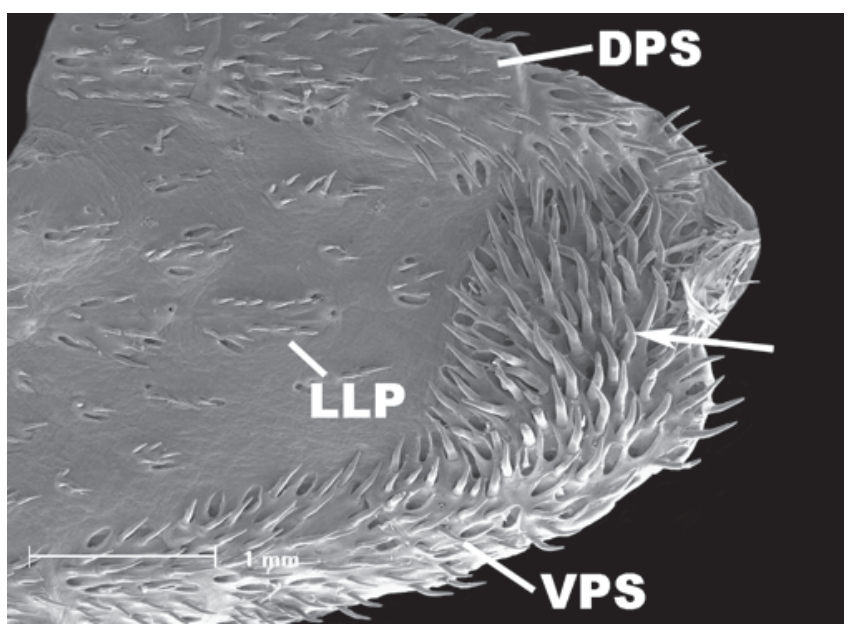

Fig. 4. Scanning electron microscope image of dermal plates at posterior end of caudal peduncle. Gymnotocinclus anosteos, paratype, MCP 41726, male, $40.5 \mathrm{~mm} \mathrm{SL}$. LLP = lateral line plates, VPS $=$ ventral plate series, DPS $=$ dorsal plate series. Arrow indicates the modified odontode tips of the last plates on caudal peduncle.

three raised crests of odontodes on posterior portion of parieto-supraoccipital. Odontodes on trunk with uniform size and distribution, not arranged into distinct rows, except for larger odontodes on ventral surface of pectoral-fin spine, and first pelvic- and anal-fin unbranched rays. Odontodes of pelvic fin turned mesially. Tip of odontodes on last lateral plates curved dorsally or anteriorly (Fig. 4).

Anterior margin of mesethmoid rounded, not expanded lat- 


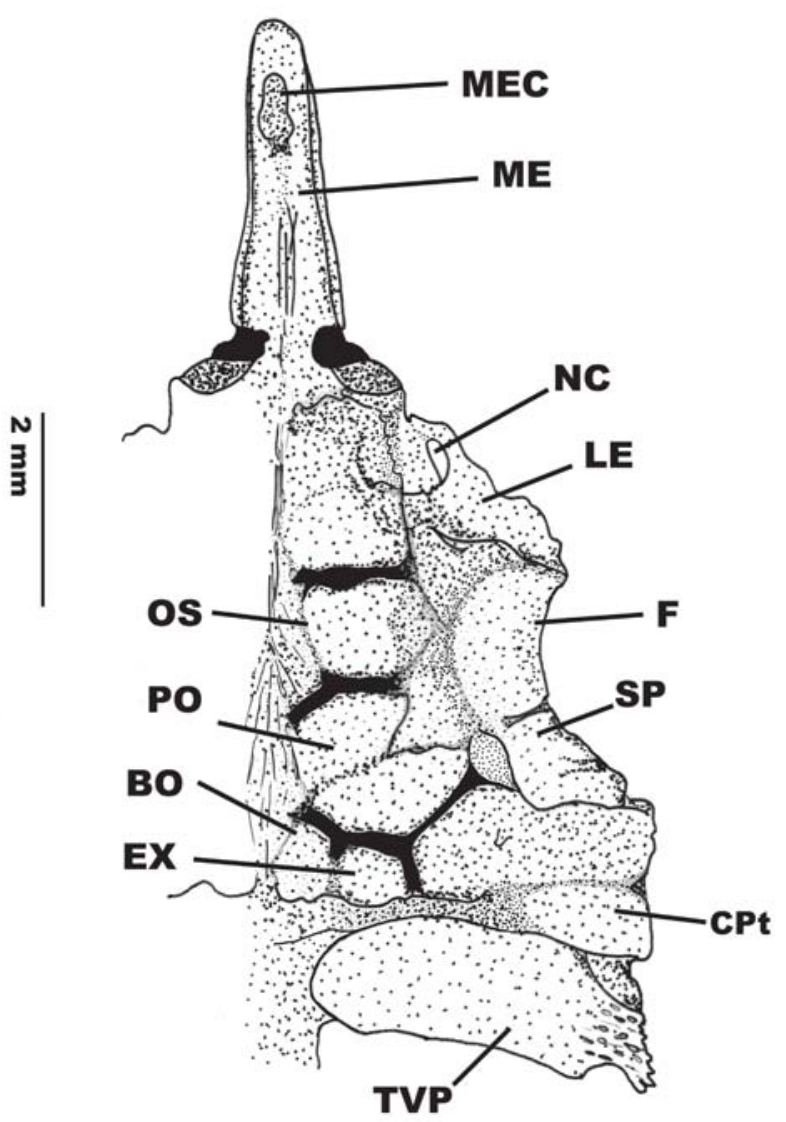

Fig. 5. Left side of neurocranium in ventral view of Gymnotocinclus anosteos, MCP 41726, paratype, male, 40.5 $\mathrm{mm}$. erally. Ventral surface of mesethmoid anterior to ventral articular condyle simple, without anteroventral lamina. Vertical lateral ethmoid ridge elevated, posterior portion contacting metapterygoid. Lateral ethmoid encapsulating nasal organ, with small longitudinal opening at lateral border of nasal capsule (Fig. 5). Lateral ethmoid exposed on dorsal surface of head posterior to nostrils supporting one series of odontodes (Fig. 8). Hyomandibula articular condyle contacting prootic. Compound pterotic not enlarged posterolaterally, posterior portion somewhat rounded, not pointed. Anteroventral margin of compound pterotic with irregularly arranged perforations of median to large size. Swimbladder capsule relatively enlarged, its posterior margin extending to joint of Weberian complex with

Table 1. Descriptive morphometrics of Gymnotocinclus anosteos. Values are given for holotype $(\mathrm{H})$ and ranges of 20 specimens including the holotype. $\mathrm{SD}=$ standard deviation.

\begin{tabular}{lcccccc}
\hline Character & $\mathrm{H}$ & $\mathrm{N}$ & Low & High & Mean & SD \\
\hline Standard length (mm) & 44.3 & 20 & 28.8 & 44.3 & 35.7 & \\
& Percentages of standard length \\
Head length & 33.0 & 20 & 32.5 & 34.4 & 33.3 & 0.56 \\
Predorsal length & 45.7 & 20 & 43.5 & 48.4 & 46.1 & 1.03 \\
Dorsal-fin spine length & 20.7 & 20 & 19.2 & 22.6 & 20.9 & 0.86 \\
Anal-fin unbranched ray length & 17.8 & 20 & 16.3 & 20.3 & 18.0 & 1.02 \\
Pectoral-fin spine length & 20.6 & 19 & 16.6 & 23.7 & 20.3 & 1.72 \\
Pelvic-fin unbranched ray length & 20.0 & 20 & 15.7 & 20.5 & 18.0 & 1.47 \\
Cleithral width & 26.7 & 20 & 24.6 & 27.0 & 25.8 & 0.71 \\
Trunk length & 17.0 & 20 & 15.2 & 17.3 & 16.2 & 0.71 \\
Abdominal length & 22.8 & 20 & 19.9 & 23.2 & 21.6 & 1.06 \\
Body depth at dorsal-fin origin & 19.1 & 20 & 16.4 & 19.7 & 17.5 & 0.86 \\
Caudal-peduncle length & 32.0 & 20 & 28.6 & 35.6 & 32.2 & 1.52 \\
Caudal-peduncle depth & 10.5 & 20 & 8.5 & 10.5 & 9.7 & 0.47 \\
& Percentages of head length & & & \\
Snout length & 58.6 & 20 & 54.7 & 62.0 & 57.9 & 1.87 \\
Orbital diameter & 14.0 & 20 & 12.6 & 16.7 & 14.5 & 1.04 \\
Interorbital width & 41.5 & 20 & 37.8 & 42.8 & 39.7 & 1.34 \\
Head depth & 50.8 & 20 & 43.4 & 50.9 & 48.1 & 1.75 \\
Suborbital depth & 28.5 & 20 & 20.7 & 28.5 & 24.7 & 2.18 \\
Mandibular ramus & 13.3 & 20 & 10.3 & 14.8 & 12.7 & 1.34 \\
\hline
\end{tabular}

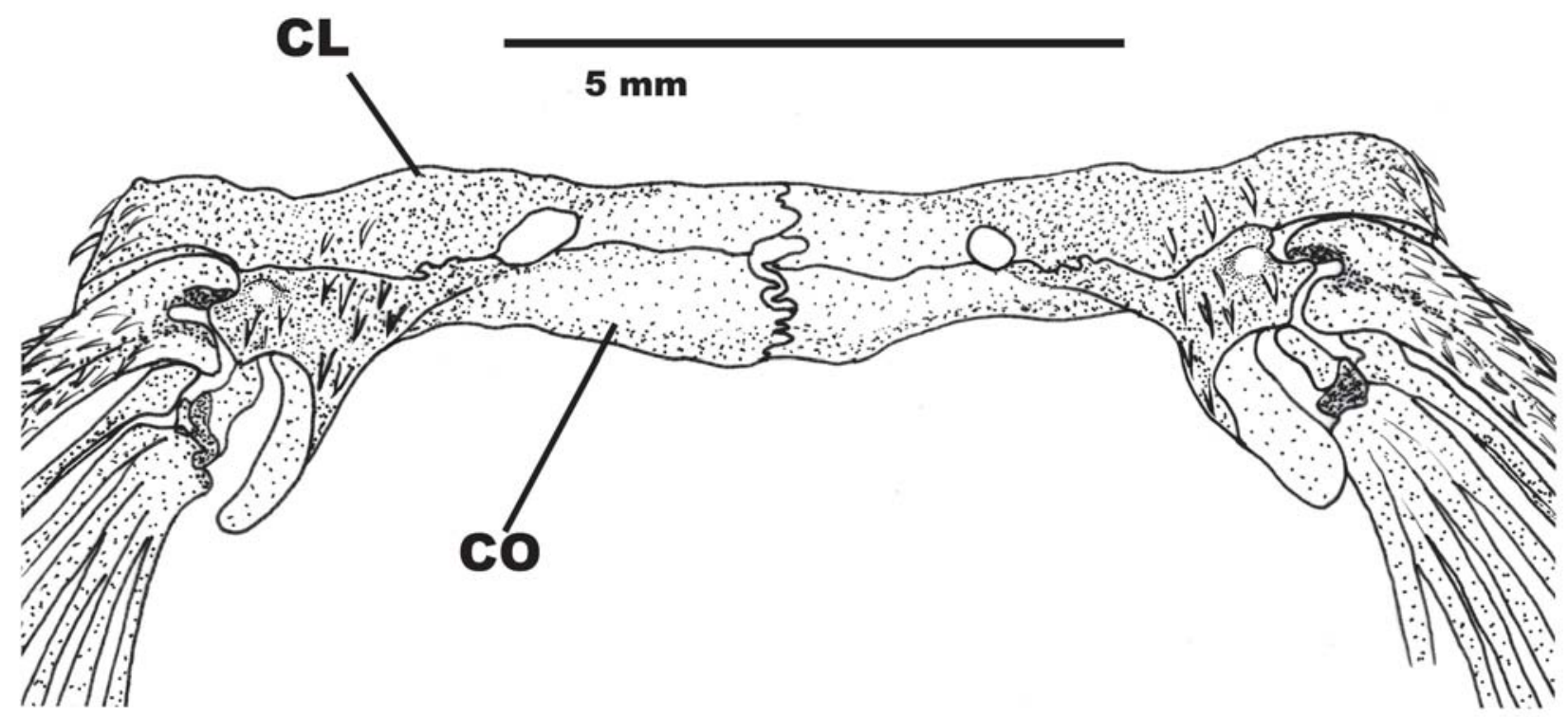

Fig. 6. Pectoral girdle in ventral view of Gymnotocinclus anosteos, MCP 41726, paratype, male, 40.5 mm. 


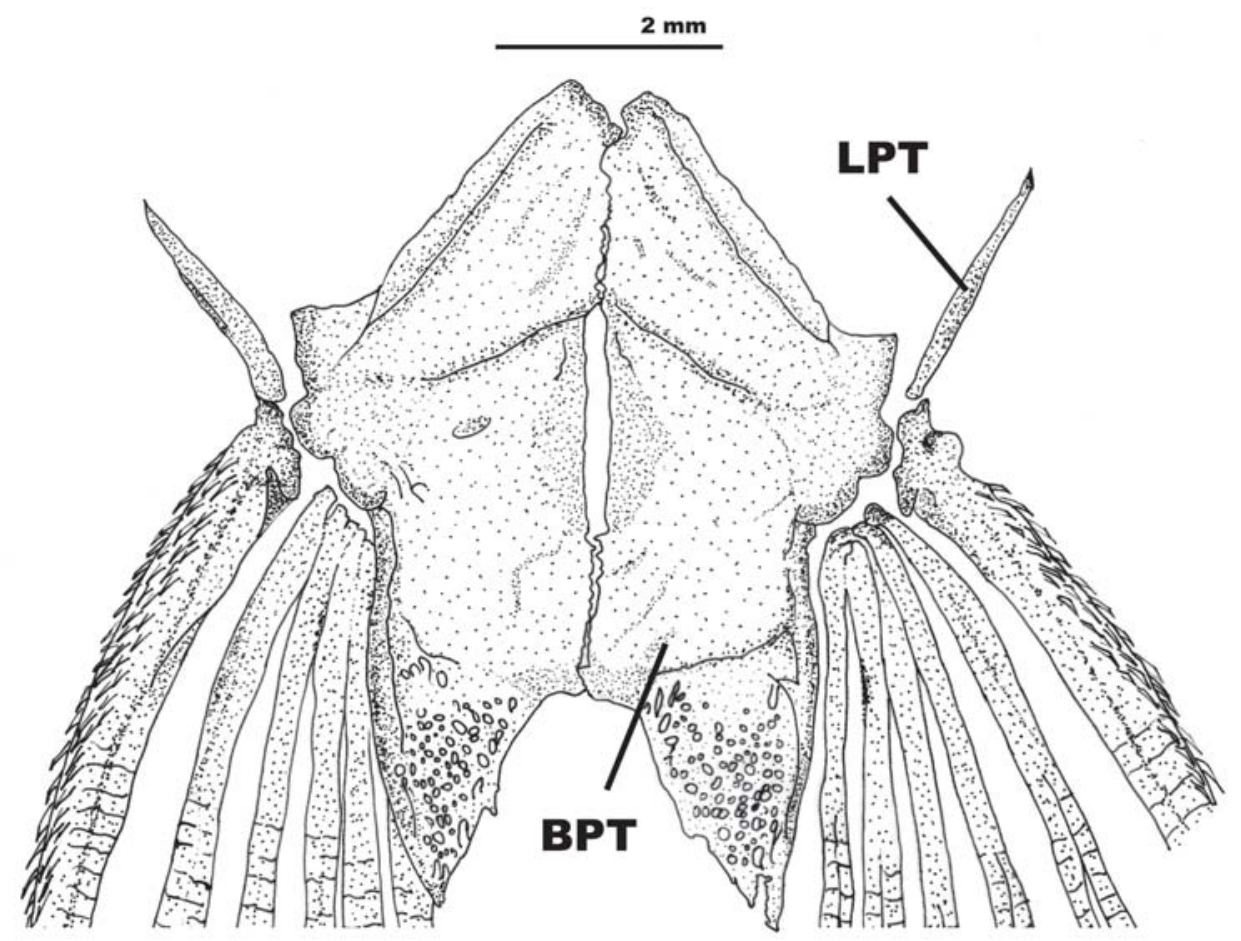

Fig. 7. Pelvic girdle in dorsal view of Gymnotocinclus anosteos, MCP 41726, paratype, male, $40.5 \mathrm{~mm}$.

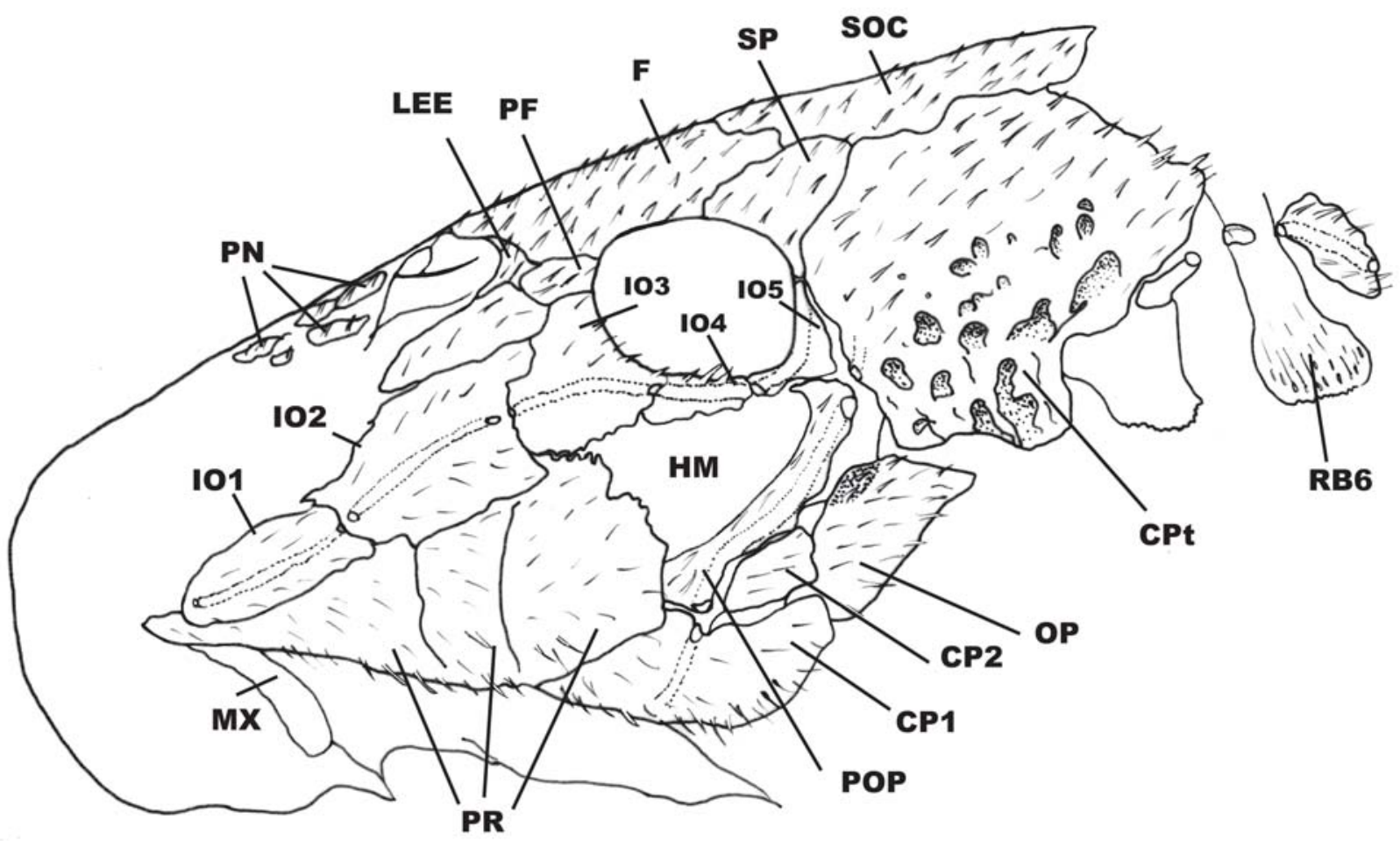

$5 \mathrm{~mm}$

Fig. 8. Skull in lateral view of Gymnotocinclus anosteos, MCP 41726, paratype, male, $40.5 \mathrm{~mm}$. 
Table 2. Frequency distribution for meristics of Gymnotocinclus anosteos. Holotype values are marked with an asterisk. $\mathrm{N}=$ number of specimens.

\begin{tabular}{llcc}
\hline Character & Frequency Distribution & N & Mean \\
\hline Left perforate plates & $23(5) 24\left(12^{*}\right) 25(3)$ & 20 & 24.0 \\
Right perforate plates & $23\left(8^{*}\right) 24(7) 25(5)$ & 20 & 23.8 \\
Left premaxillary teeth & $25(1) 26(1) 27(2) 28\left(5^{*}\right) 29(3) 30(1) 31(2) 32(2) 35(1)$ & 18 & 29.1 \\
Right premaxillary teeth & $25(1) 26\left(2^{*}\right) 27(4) 28(3) 29(1) 30(1) 31(1) 32(1) 33(4) 34(1)$ & 19 & 29.3 \\
Left dentary teeth & $23(1) 25(2) 26(3) 27\left(3^{*}\right) 28(4) 29(2) 30(2) 33(2)$ & 19 & 27.8 \\
Right dentary teeth & $22(1) 25(3) 26(3) 27\left(2^{*}\right) 28(1) 29(4) 30(1) 31(1) 32(1) 33(1) 35(1)$ & 19 & 28.0 \\
\hline
\end{tabular}

sixth centrum. Metapterygoid channel present, deep. Levator crest present, well developed, its extension not reaching dorsal portion of hyomandibula. Hyomandibula adductor crest present, extending from posterior corner of preopercle to dorsal articular condyle. Suture between metapterigoid and hyomandibula elongate, beginning almost on dorsal margin of bones (Fig. 9). Preopercle laterosensorial canal straight, posterior ramus contacting hyomandibula adductor crest. Preopercle ventral margin straight, not reflected medially.

Teeth slender, bifid; major (medial) cusp slightly rounded and approximately three times longer than minor (lateral) cusp, minor cusp minute and pointed. Accessory teeth absent in premaxilla and dentary. Lips roundish, papillose, and comparatively large; anterior portion of lips well developed and fleshy, posterior portion almost reaching pectoral girdle. Maxillary barbel adnate, completely attached to lower lip.

Upper pharyngeal toothplate larger than fourth pharyngobranchial, which partially supports it. Accessory ceratobranchial flange present and well developed, almost same size of first ceratobranchial. Basibranchial 2 and 4 present. Basibranchial 2 partially ossified. Four branchiostegal rays (Fig. 10).

Color in alcohol. Ground color of dorsal surface of head and body light to dark brown. Dorsal surface of head darker than body. Ventrolateral margins of head and trunk yellowish. Ven- tral surface yellowish and almost unpigmented. Wide longitudinal dark lateral stripe. Lateral line unpigmented, forming thin light longitudinal line in middle of dark lateral stripe. Four transverse dark saddles on dorsum, beginning at dark lateral longitudinal stripe and extending to middorsal line. Most anterior saddle inconspicuous, at dorsal-fin origin; second saddle beginning at end of dorsal-fin base and reaching vertical through second branched anal-fin ray; third saddle at typical adiposefin region; and posterior saddle at end of caudal peduncle. Pectoral and pelvic fins mostly hyaline, with few scattered chromatophores. Dorsal and anal fins with chromatophores forming two transverse dark bands, most conspicuous on dorsal fin. Caudal fin mostly dark, except for transverse hyaline band at middle and posterior end of rays. In some specimens, middle caudal rays darker forming longitudinal stripe.

Sexual dimorphism. Males with urogenital papilla just behind the anal opening. Adult males have a fleshy flap along the dorsal margin of the pelvic-fin thickened ray, which is wider basally and progressively narrowing distally. The flap is absent in juveniles and females.

Distribution. Gymnotocinclus anosteos is known only from two creeks, both tributaries to the rio Tocantinzinho, in the headwaters of the rio Tocantins basin, Goiás, Brazil (Fig. 11).

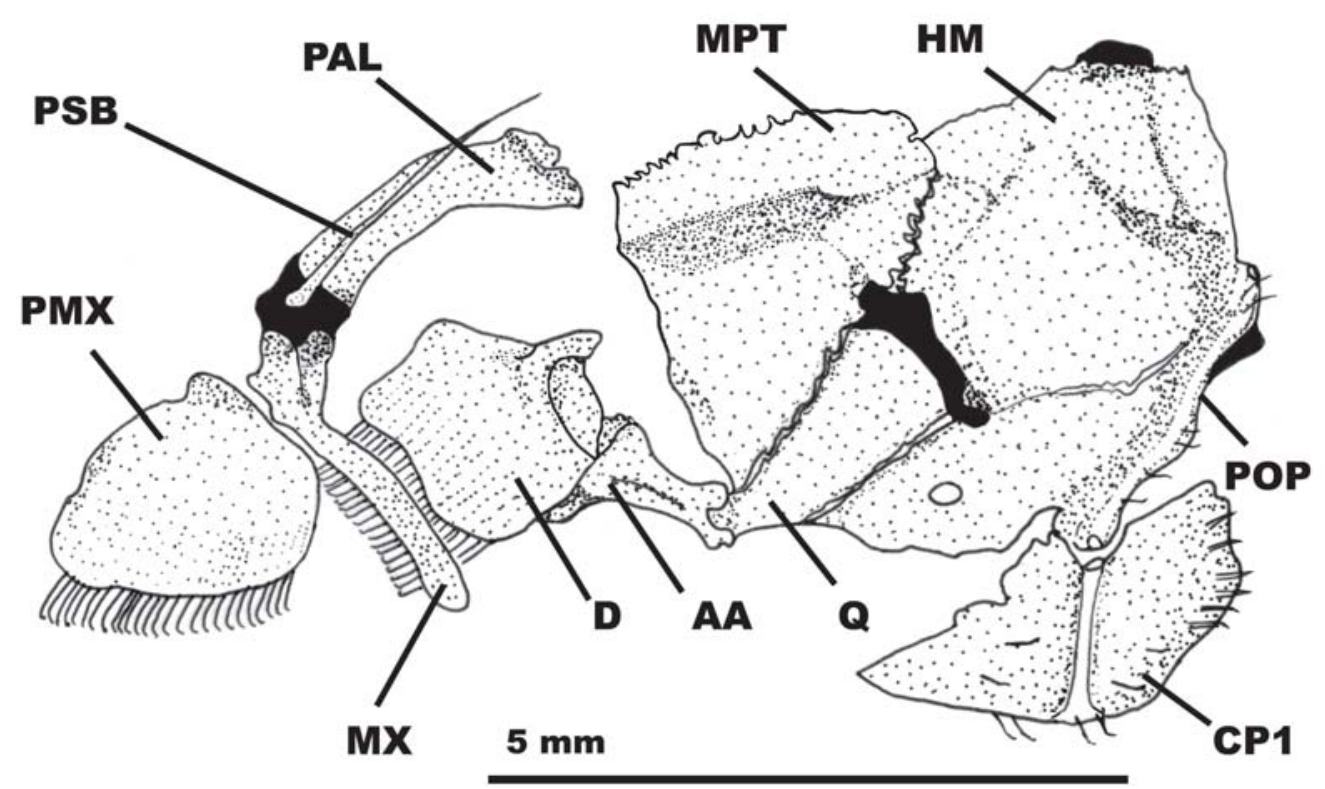

Fig. 9. Suspensorium in lateral view of Gymnotocinclus anosteos, MCP 41726, paratype, male, $40.5 \mathrm{~mm}$. 
Etymology. From the Greek anosteos, meaning boneless, in allusion to the absence of the lateral connecting bone.

\section{Discussion}

The extreme reduction of dermal plates of Gymnotocinclus anosteos makes impossible the observation of seven out of the 46 characters described by Schaefer (1998; characters 32$35,39-41)$. Other characters described by that author and included in subsequent phylogenies (Gauger \& Buckup, 2005; Ribeiro et al., 2005) are described above. The main focus of the present study is to describe a new taxon, and a new phylogeny of hypoptopomatines is beyond the aim of this study. However, the examination of several characters allows the allocation of the new taxon among hypoptopomatines, prompts the description of a new genus, and permits the discussion of its position among other genera.

The presence of a laterally exposed pectoral girdle, a compound pterotic pierced by numerous enlarged fenestrae, a metapterygoid channel, and a partially closed arrector fossae of the ventral pectoral girdle indicates that Gymnotocinclus anosteos belongs to the Hypoptopomatinae (Schaefer, 1991; 1998). Two additional synapomorphies for hypoptopomatines (Schaefer, 1998) could not be verified in Gymnotocinclus due to the plate reduction: presence of a medial rostral snout plate and presence of enlarged odontodes on both dorsal and ventral snout margins. Gymnotocinclus does not have an open nasal capsule, a synapomorphy proposed by Schaefer (1998) for the subfamily and, instead, shares with Acestridium an enclosed nasal capsule. However, Acestridium is well nested within the subfamily phylogeny and no other features suggest a closer relationship between Gymnotocinclus and Acestridium. Thus, we interpret the enclosed nasal capsule of Gymnotocinclus to be plesiomorphic for the submfamily as opposed to the derived condition of an open nasal capsule found in all other hypoptopomatines except Acestridium.

A condition in which the pectoral girdle is exposed only laterally appears to be plesiomorphic for hypoptopomatines according to the analysis of Gauger \& Buckup (2005: ch. 53:1). Gymnotocinclus shares this feature with the basal Eurycheilichthys and Parotocinclus jumbo, suggesting a basal position for the new genus.

The presence of an adnate maxillary barbel similar to that of Gymnotocinclus, was described by Britski (1997) as a diagnostic feature of Corumbataia, and this could suggest a close relationship between these two genera. However, Gymnotocinclus has the exposed portion of the pectoral girdle limited to the lateral portion, differing from Corumbataia which posseses the pectoral girdle almost completely exposed. The new taxon also lacks other diagnostic features of Corumbataia (Britski, 1997). An adnate maxillary barbel appears in most neoplecostomines (Armbruster, 2004, ch. 181), as well as in Parotocinclus jumbo and at least one species of Kronichthys. For this reason, an adnate maxillary barbel seems to be a plesiomophic feature within the Hypoptopomatinae.

The new genus lacks the pectoral-fin slit, a dermal pore between the lateral process of cleithrum and the insertion of the pectoral fin (Reis \& Schaefer, 1998). The presence of this character was mapped by Reis \& Schaefer (1998) onto the cladogram of the subfamily relationships of Schaefer (1998).

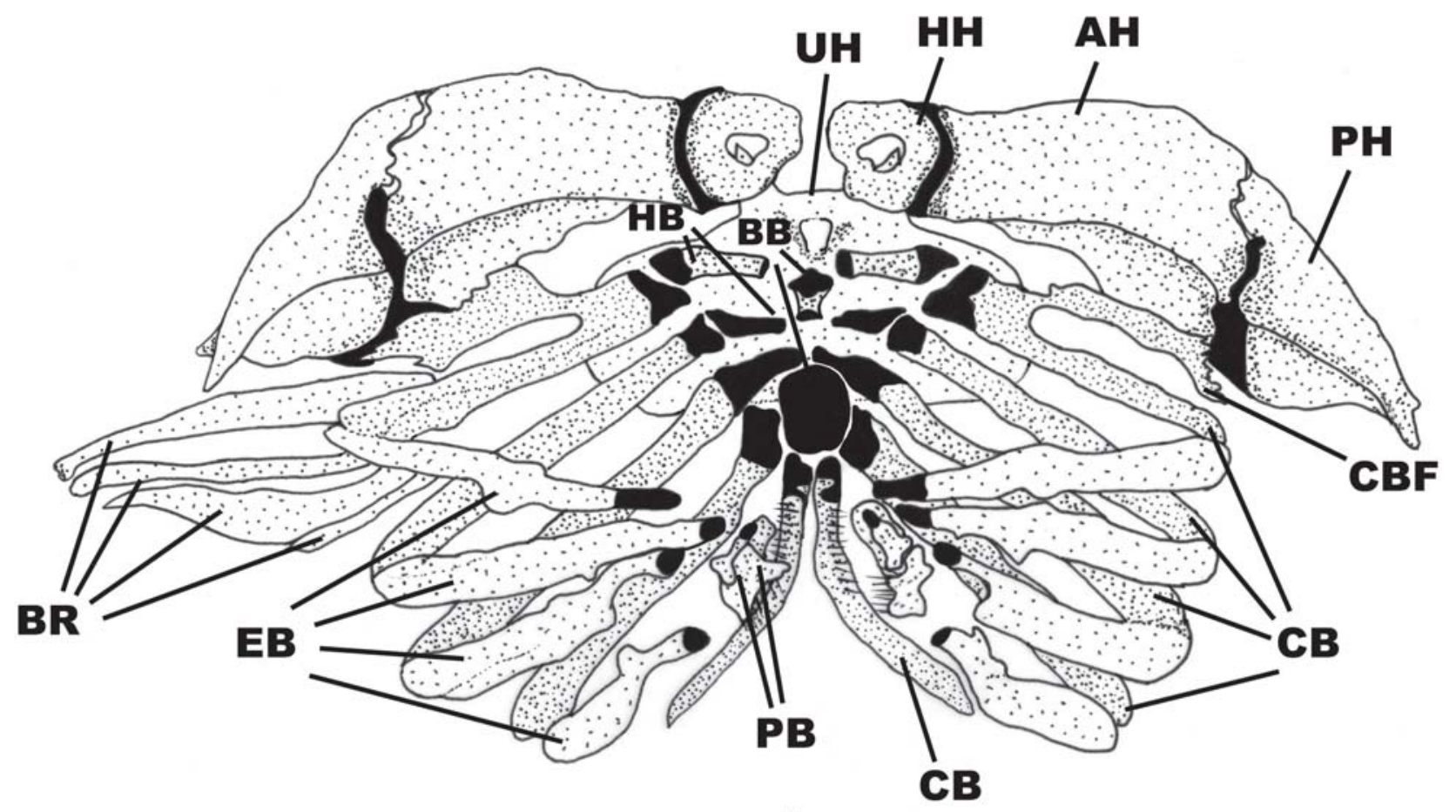

$5 \mathrm{~mm}$

Fig. 10. Branchial skeleton in dorsal view of Gymnotocinclus anosteos, MCP 41726, paratype, male, $40.5 \mathrm{~mm}$. 
They concluded that the pectoral slit evolved on the root of hypoptopomatines with subsequent reversions on more inclusive clades (Reis \& Schaefer, 1998, fig. 11). Gauger \& Buckup (2005) also included the pectoral-fin slit character in their analysis of the subfamily (ch. 57), which separated $\mathrm{Pa}$ -

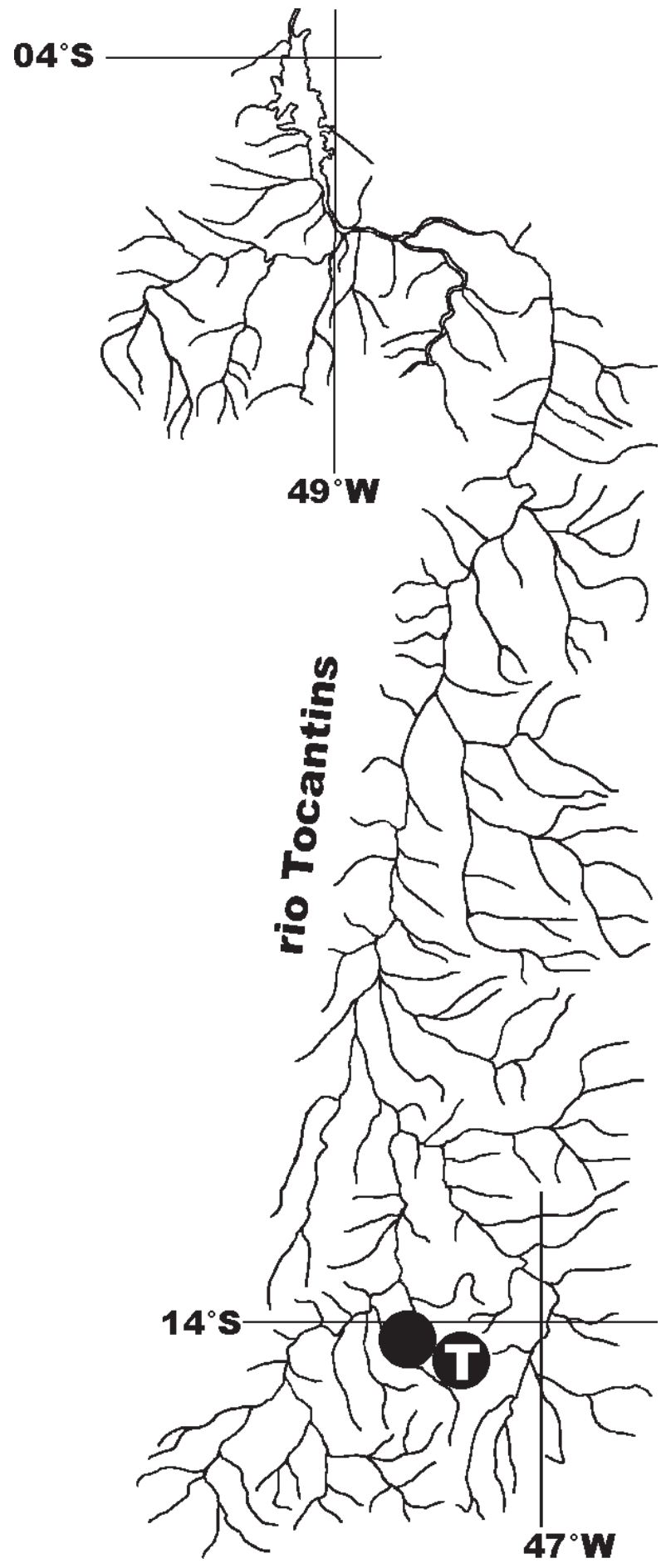

Fig. 11. Geographic distribution of Gymnotocinclus anosteos in the upper rio Tocantins drainage. Circles represent collecting sites, and $\mathrm{T}$ is the type-locality. rotocinclus jumbo from all remaining genera. Thus, the absence of a pectoral-fin slit in Gymnotocinclus also suggests a basal position within hypoptopomatines.

An extreme reduction on plate covering in loricariids was reported previously for the genus Lithogenes Eigenmann, 1909, and for Pareiorhaphis nudulus (Reis \& Pereira, 1999). These taxa are not closely related, indicating three independent events of plate reduction in the family. Although this condition must be considered autapomorphic for Gymnotocinclus anosteos, some similarities related to plate reduction between this species and $P$. nudulus deserve mention. Both Gymnotocinclus and P. nudulus lack an adipose fin and, instead, have a series of unpaired platelets on the adipose-fin position. The presence of these platelets is an independent derived feature for $P$. nudulus and Gymnotocinclus, indicating that the plate reduction event was concomitant with the loss of the adipose fin. Also, Gymnotocinclus and P. nudulus share the lack of the lateral connecting bone. The absence of a connecting bone is uniquely derived for the new genus within hypoptopomatines and seems also to covary with the plate reduction.

Gymnotocinclus lacks bifid hemal spines, which distinguishes the new genus from all remaining hypoptopomatines. This feature was examined by Armbruster (2004) and according to that author is shared by the Delturinae, most Hypostominae, Pareiorhaphis nudulus and Pareiorhaphis splendens.

Gymnotocinclus possesses a uniquely derived modification of the odontodes of the last median plate series on the caudal peduncle. A similar structure was previously described for males of some species of Otocinclus (Aquino, 1994; Schaefer, 1997; Reis, 2004). The modification in Otocinclus was described as a contact organ which is probably involved in breeding and plays a role in male courtship. However, the presence of the modified odontode orientation in both males and females of Gymnotocinclus is likely to be nonhomologous with the character in Otocinclus and at this time it is impossible to determine if it is a true contact organ.

In summary, despite the lack of a formal phylogenetic analysis including the new genus among hypoptopomatines, the discussion presented above provides evidence that Gymnotocinclus has a basal position in the subfamily, based on the possession of an enclosed nasal capsule, the pectoral girdle exposed only laterally, the maxillary barbel adnate to the lower lip, and the absence of a pectoral-fin slit.

Comparative material. Acestridium sp. A: MCP 37784, $11+2$ c\&s, Brazil, Amazonas, Humaitá, rio Traíra on Transamazon Road. Corumbataia cuestae: LBP 1309, $47+3$ c\&s, Brazil, São Paulo, Bofete, córrego da Jacutinga. Epactionotus bilineatus: MCP 29293, $29+3$ c\&s, Brazil, Rio Grande do Sul, Itati, arroio das Bananeiras. Eurycheilichthys limulus: MCP 22700, $48+2$ c\&s, Brazil, Rio Grande do Sul, Cruz Alta, rio Passo Novo. Eurycheilichthys pantherinus: MCP 35042, $17+3$ c\&s, Brazil, Rio Grande do Sul, Bom Jesus, rio dos Touros on road from Rondinha to Silveira. Lampiella gibosa: MCP 31588, $1+1$ c\&s, Brazil, São Paulo, Barra do Turvo, rio Bonito tributary to rio Pardo. Hypoptopoma gulare: MCP 35890, 2, Brazil, 
Acre, Bujari, igarapé Mapinguari on highway BR-364. Hisonotus insperatus: MCP 28279, $4+1$ c\&s, Brazil, Minas Gerais, Abadia dos Dourados, rio Preto on the road from Palmito to Abadia dos Dourados. Hisonotus notatus: MCP 18098, $204+4$ c\&s, Brazil, Espírito Santo, rio São José dos Torres on highway BR-101. Kronichthys subteres: MCP 20152, $118+2$ c\&s, Brazil, São Paulo, Iporanga, córrego Seco at Bairro da Serra. Microlepidogaster perforatus: MCP 17717, 4 + 1 c\&s, Brazil, Minas Gerais, Carandaí, rio Carandaí. Nannoptopoma sternoptychum: MCP 35880, 1, Brazil, Acre, Xapurí, rio Iná. Neoplecostomus espiritosantensis: MCP 34358 , 2, Brazil, Espírito Santo, Muniz Freire, Córrego Santo Antonio, tributary to rio Itapemirim. Neoplecostomus franciscoensis: MCP 34212, 17, Brazil, Minas Gerais, Nova Lima, Ribeirão dos Cristais tributary to rio das Velhas. Neoplecostomus microps: MCP 12199, 19+2 c\&s, Brazil, São Paulo, Monteiro Lobato, creek tributary of rio Buquira on highway SP-150. MCP 20057, 12, Brazil, São Paulo, Arapei, creek tributary to rio Bananal on highway SP-66. Niobichthys ferrarisi: MCP 34810, $2+1$ c\&s, Venezuela, Amazonas, rio Bária. Otothyris travassosi: MCP 18105, paratypes, $28+2$ c\&s, Brazil, Espírito Santo, Boa Esperança, rio Braço Norte on highway ES-130. Otothyris rostrata: MCP 36786, 3 + 1 c\&s, Uruguay, Maldonado, creek tributary to rio Cebollati. Otothyropsis marapoama: MCP 38303, paratypes, 9+ 1 c\&s, Brazil, São Paulo, Catanduva, córrego Cubatão. Otocinclus flexilis: MCP 17414, $11+2$ c\&s, Brazil, Rio Grande do Sul, Capão do Leão, arroio Itaetá at Passo das Pedras. Oxyropsis wrightiana: MCP 34503, 24+3 c\&s, Peru, Loreto, lago Tamara at rio Pacaya. Pareiorhaphis hypselurus: MCP 26108, 9, Brazil, Rio Grande do Sul, Maquiné, arroio Pinheiro. Pareiorhaphis nudulus: MCP 10436, paratypes, $103+8 \mathrm{c} \& s$, Brazil, Santa Catarina, Nova Veneza, rio Jordão Alto. Pseudotocinclus tietensis: MCP 20090, $2+1$ c\&s, Brazil, São Paulo, Salesópolis, riacho Paraitinguinha on road from Salesópolis to Jacareí. Pseudotothyris obtusa: MCP 31728, $7+2$ c\&s, Brazil, São Paulo, Itanhaém, creek tributary to rio Preto, about $2 \mathrm{~km}$ from airport. Parotocinclus maculicauda: MCP 31591, $50+4$ c\&s, Brazil, São Paulo, Barra do Turvo, rio Bonito tributary to Rio Pardo. Parotocinclus jumbo: MCP 31107, $84+7$ c\&s, Brazil, Alagoas, Batalha, rio Ipanema at Batalha. Parotocinclus prata: MCP 28303, $44+2$ c\&s, Brazil, Minas Gerais, Guarda-Mor, córrego Macaúba affluent of rio Claro on the road from Coromandel to Guarda-Mor. Schizolecis guentheri: MCP 31558, 100+3 c\&s, Brazil, Rio de Janeiro, Parati, Rio São Roque on highway BR-101 near Tarituba.

\section{Acknowledgments}

We are grateful to E. Pereira for the discussions about loricariid anatomy and characters. Thanks to the Centro de Microscopia e Microanálises - CEMM, PUCRS for the SEM preparations. Thanks to M. Lucena and J. Verba (MCP), M. Sabaj (ANSP) for support in the museum collections, and especially M. Azevedo (MCN), for the donation of paratypes to other institutions. Thanks to the "All Catfish Species Inventory" project (NSF DEB \#0315963) that provided funding to visit collections for TPC. We are also grateful to the Conselho Nacional de Desenvolvimento Científico e Tecnológico for financial support (TPC process \#132879/20069, and RER process \#301748/2004-7).

\section{Literature Cited}

Aquino, A. E. 1994. Secondary sexual dimorphism of the dermal skeleton in two species of the hypoptopomatinae genus
Otocinclus (Siluriformes: Loricariidae). Ichthyological Exploration of Freshwaters, 5(3): 217-222.

Armbruster, J. W. 2004. Phylogenetic relationships of the suckermouth armoured catfishes (Loricariidae) with emphasis on the Hypostominae and the Ancistrinae. Zoological Journal of the Linnean Society, 141:1-80.

Boeseman, M. 1968. The genus Hypostomus Lacépède, 1803, and its Surinam representatives (Siluriformes, Loricariidae). Zoologische Verhandelingen, 99: 1-89.

Britski, H. A. 1997. Descrição de um novo gênero de Hypoptopomatinae, com duas espécies novas (Siluriformes, Loricariidae). Papéis Avulsos de Zoologia, 40(15): 231-255.

Gauger, M. F. W. \& P. A. Buckup. 2005. Two new species of Hypoptopomatinae from rio Paraíba do Sul basin, with comments on the monophyly of Parotocinclus and Otothyrini (Siluriformes: Loricariidae). Neotropical Ichthyology, 3(4): 509-518.

Lehmann, P. 2006. Anatomia e relações filogenéticas da família Loricariidae (Ostariophysi: Siluriformes) com ênfase na subfamília Hypoptopomatinae. Unpublished Ph.D. Dissertation. Pontifícia Universidade Católica do Rio Grande do Sul, Porto Alegre, Brazil.

Reis, R. E. 2004. Otocinclus cocama, a new uniquely colored loricariid catfish from Peru (Teleostei: Siluriformes), with comments on the impact of taxonomic revisions to the discovery of new taxa. Neotropical Ichthyology, 2(3): 109-115.

Reis, R. E. \& T. P. Carvalho. 2007. Hypoptopomatinae. Pp. 83-84. In: P. A. Buckup, N. A. Menezes \& M. S. Ghazzi (Eds.). Catálogo das espécies de peixes de água doce do Brasil. Museu Nacional (Série Livros), Rio de Janeiro, Brazil.

Reis, R. E. \& S. A. Schaefer. 1998. New Cascudinhos from Southern Brazil: Systematics, Endemism, and Relationships (Siluriformes, Loricariidae, Hypoptopomatinae). American Museum Novitates, 3254:1-25.

Ribeiro, A. C., M. Carvalho \& A. L. A. Melo. 2005. Description and relationships of Otothyropsis marapoama, a new genus and species of Hypoptopomatinae catfish (Siluriformes: Loricariidae) from Tietê basin, southeastern Brazil. Neotropical Ichthyology, 3(4): 489-498.

Schaefer, S. A. 1991. Phylogenetic analysis of the loricariid subfamily Hypoptopomatinae (Pisces: Siluroidei: Loricariidae), with comments on generic diagnoses and geographic distribution. Zoological Journal of the Linnean Society, 102: 1-41.

Schaefer, S. A. 1997. The Neotropical cascudinhos: systematics and biogeography of the Otocinclus catfishes (Siluriformes: Loricariidae). Proceedings of the Academy of Natural Sciences of Philadelphia, 148: 1-120.

Schaefer, S. A. 1998. Conflict and resolution: Impact of new taxa on phylogenetic studies of the neotropical cascudinhos (Siluriformes: Loricariidae) Pp. 375-400. In: L. R. Malabarba, R. E. Reis, R. P. Vari, C. A. S. Lucena \& Z. M. S. Lucena (Eds.). Phylogeny and Classification of Neotropical Fishes. Porto Alegre, Edipucrs, 729p.

Schaefer, S. A. 2003. Loricariidae - Hypoptopomatinae (Armored catfishes) Pp. 321-329. In: R. E. Reis, S. O. Kullander \& C. J. Ferraris, Jr. (Eds.). Checklist of the Freshwater Fishes of the South and Central America. Porto Alegre, Edipucrs, 729p.

Taylor, W. R. \& G. C. Van Dyke. 1985. Revised procedures for staining and clearing small fishes and other vertebrates for bone and cartilage study. Cybium, 9(2): 107-119.

Accepted July, 2008 Published September 30, 2008 